Original Article

\title{
ANTIMICROBIAL ACTIVITY OF PHENOLIC EXTRACT OF APPLE POMACE AGAINST PAENIBACILLUS LARVAE AND ITS TOXICITY ON APIS MELLIFERA
}

\author{
Pablo Giménez-Martínez ${ }^{1,2^{*}}$ \\ Maria Ramírez-Ambrosi ${ }^{3}$ \\ Maria Alonso-Salces Rosa ${ }^{1,4}$ \\ Blanca Gallo 3 \\ Angel Berrueta Luis 3 \\ Matias Maggi ${ }^{1,4}$ \\ Sandra Fuselli ${ }^{1,5}$ \\ 'Centro de Investigación en Abejas Sociales, Facultad de Ciencias Exactas y Natu- \\ rales, Universidad Nacional de Mar del Plata, Funes 3350, Mar del Plata, Argentina \\ ${ }^{2}$ Agencia Nacional de Promoción Científica y Tecnológica, Godoy Cruz 2370 (CABA), \\ Buenos Aires, Argentina \\ ${ }^{3}$ Grupo de Investigación de Química Analítica de Productos Naturales, Departa- \\ mento de Química Analítica, Facultad de Ciencia y Tecnología, Universidad del País \\ Vasco/EuskalHerriko Unibertsitatea (UPV/EHU), Barrio Sarriena, Bilbao, Spain \\ ${ }^{4}$ Consejo Nacional de Investigaciones Científicas y Técnicas (CONICET), Godoy Cruz \\ 2290 (CABA), Buenos Aires, Argentina \\ ${ }^{5}$ Comisión Investigaciones Científicas de la Provincia de Buenos Aires (CIC), 526 st \\ between 10 and 11, La Plata, Argentina \\ *corresponding author: beedarian@gmail.com \\ Received: 28 November 2018; accepted: 22 June 2020
}

A b s t ract

Apis mellifera populations are exposed to different biotic and abiotic stressors that affect bee survival. Paenibacillus larvae, the causative agent of American foulbrood, is one of the most important bacterial pathogens that affect bee health. In some countries, the use of antibiotics is the most common method for the prevention and treatment of $P$. larvae infected colonies, however this application can also increase the risk of occurrence of resistant strains. An ecological alternative is the use of vegetal extracts containing bioactive compounds, such as polyphenols. The aim of this study is to check the antimicrobial activity of phenolic extracts of apple pomace, from the cider industry, against $P$. larvae strains by the broth micro dilution method. In addition, the toxicity of the phenolic extracts on $A$. mellifera was verified using the complete exposure method. All extracts contain from 715.31 to $11348.16 \mu \mathrm{g} g \mathrm{l} / \mathrm{g}$ DW, determined by Folin-Ciocalteu show antimicrobial activity against $P$. larvae genotype ERIC I, ranging from $23 \mu \mathrm{g} / \mathrm{mL}$ to $150 \mu \mathrm{g} / \mathrm{mL}$. Toxicity assays of apple pomace extracts on adult bees exhibited a maximum mortality of $18 \%$ after $48 \mathrm{~h}$. This promising alternative will be used in the future to evaluate its toxicity at a field level.

Keywords: antimicrobial activity, Apis mellifera, Apple pomace, Paenibacillus larvae, phenolic extract

\section{INTRODUCTION}

Apis mellifera populations are exposed to different biotic and abiotic stressors that affect bee survival. Pathogens and parasites are among the most important factors that affect bee mortality (Goulson et al., 2015). This phenomenon triggers negative consequences not only for the environment but also for beekeepers who suffer severe economic losses 
associated with their honeybee colonies.

Paenibacillus larvae is the causal agent of the American foulbrood, the most severe bacterial disease that affects honeybee larvae. It kills infected larvae and is potentially lethal for the entire colony (Genersch et al., 2006). P. larvae spores are resistant to heat, desiccation and diverse disinfectants, which is a problem for beekeepers when they attempt to reduce their effects (Genersch, 2010; Thompson et al., 2007). In some countries, the use of antibiotics, particularly oxytetracycline (OTC) (Genersch, 2010; Hansen \& Brødsgaard, 1999), was the most common method for the prevention and treatment of infected colonies. However, in most European countries the use of antibiotics is banned since it is known to generate such problems as the presence of chemical residues in beehive products (honey, pollen and wax), which may affect consumers' health. Furthermore, the antibiotic application can affect the life of bees and increase the risk of occurrence of resistant strains (Martel et al., 2006). To date, the presence of OTC resistant strains has been reported in Argentina, United States, Italy, New Zealand and United Kingdom (Alippi, 1996; Evans, 2003; Miyagi et al., 2000). In Argentina, in 2016, the National Service for Agrifood Health and Quality (SENASA, 2016) withdrew those made with the active ingredient oxytetracycline from the list of approved veterinary products for use in beekeeping (http://www.senasa.gob. ar/senasa-comunica/noticias/se-recuerda-queno-esta-permitido-el-uso-de-antibioticos-enlas-colmenas).

Propolis, vegetal extracts or secondary metabolites were studied an ecological alternative to synthetic drugs against the action of pathogens, essential oils or their constituents (Alonso-Salces et al., 2017). These compounds exhibit a retarded or inhibitory action against bacteria, yeasts and molds (Damiani et al., 2014; Fuselli et al., 2006; Gende et al., 2008, 2010). Phenolic compounds establish one of the largest groups of secondary metabolites widely distributed in the plant kingdom. They are essential for their contribution to plant, morphology, growth, and development and accomplish an important role in plant defense mechanisms against biotic and abiotic external agents (Bravo, 1998). Several studies are based on the use of phenolic compounds as antimicrobial agents. Mihai et al. (2012) correlated the total polyphenol content in propolis from different geographical origins with their antibacterial activity against $P$. larvae. The authors found that the activity against the pathogen depends on the phenolic families present in the extracts. Agourram et al. (2013) determined the composition of polyphenols in several fruits and vegetables and established their antimicrobial activity. Among the analyzed extracts, the apple peel extract showed the highest inhibitory activity against Staphylococcus aureus and Pseudomonas fluorescens. Cirilli et al. (2015) studied the antimicrobial effect of the polyphenols present in the variety Italian red passion against gram-negative and grampositive bacteria, concluding that high contents of polyphenols present in this apple variety exhibited high antimicrobial activity against the two groups of bacteria. For this reason, the aim of this study was to evaluate the antimicrobial activity of the phenolic extracts of apple pomaces from the cider industry with different total phenolic contents against $P$. larvae strains and determinate the toxicity of these compounds contained in the extracts on A. mellifera.

\section{MATERIALS AND METHODS}

\section{Chemicals}

Mueller-Hinton broth, agar, brain-heart infusion, yeast extract, glucose and peptone were obtained from Britania S.A. (Ciudad Autónoma de Buenos Aires, Argentina). Sodium chloride (99.99\%) from Alun (San Martin, Buenos Aires, Argentina) and $\mathrm{K}_{2} \mathrm{HPO}_{4}(98 \%)$ from Cicarelli (San Lorenzo, Santa Fe, Argentina) were analytical grade; and sodium pyruvate (ㅇ9\%) from Biopack (Zarate, Buenos Aires, Argentina) was extra pure. Distilled water was sterilized in autoclave FAC (Buenos Aires, Argentina). Sterilized polystyrene 96-well culture plates were supplied by Deltalab (Barcelona, Spain). Acetonitrile, ethanol and methanol (HPLC grade), acetic acid (ACS 
reagent), n-butanol (FCC reagent), and resazurin sodium salt (for cell culture) were supplied by Sigma-Aldrich (Saint Louis, MO, USA); and dimethylsulfoxide (analytical grade), by Biopack (Zarate, Buenos Aires, Argentina).

\section{Samples}

Nine samples of apple pomace (a by-product of the cider making industry) were obtained using different apple cultivars from several geographical origins and types of pressing provided by cider makers in the Basque Country (Spain) (Tab. 1).

Extraction and determination of phenolic contents in apple pomace

Polyphenols were extracted from apple pomace $(0.5 \mathrm{~g})$ with $30 \mathrm{~mL}$ of methanol-water-acetic acid (30:69:1, v/v/v) containing $2 \mathrm{~g} / \mathrm{L}$ of ascorbic acid in an ultrasonic bath for $10 \mathrm{~min}$ (Ramirez-Am- brosi et al., 2013). The extract was spin-dried (3600 rpm, $4^{\circ} \mathrm{C}, 20 \mathrm{~min}$ ), frozen at $-80^{\circ} \mathrm{C}$ and freeze-dried.

The content of total phenols was estimated using the Folin-Ciocalteau reagent (Singleton \& Rossi, 1965). The content of total polyphenols in the samples of apple marc lyophilized was expressed as $\mu$ of gallic acid equivalents per $g$ of mass of lyophilized ( $\mu$ gal. ac. /g DW).

\section{Biological material}

$P$. larvae strains were isolated from the honey combs of beehives exhibiting clinical symptoms of American foulbrood, located in the Argentinian provinces of Buenos Aires, Córdoba and Entre Ríos. Strains C1 and C2 were from Balcarce, Buenos Aires province (3752's$\left.58^{\circ} 15^{\prime} \mathrm{W}\right)$, strain C6 from Rio Cuarto in the Cordoba province $\left(33^{\circ} 08^{\prime} 00^{\prime \prime} S\right.$ 64 $\left.21^{\circ} 00^{\prime \prime} 0\right)$ and strain C9 from Concordia in the Entre Rios

Table 1.

Samples of apple pomace from different apple varieties and provided by the Basque cider making industry. The total polyphenols content was measured by Folin-Ciocalteu method

(Ramirez-Ambrosi et al., 2013)

\begin{tabular}{|c|c|c|c|c|c|}
\hline $\mathrm{N}^{0}$ & Sample & Apple varieties & $\begin{array}{l}\text { Apple geographical } \\
\text { origin }\end{array}$ & $\begin{array}{l}\text { Type of } \\
\text { press }\end{array}$ & $\begin{array}{l}\text { Total polyphenols } \\
\text { content } \\
\text { ( } \mu \text { gal. ac. /g DW) }\end{array}$ \\
\hline 1 & MR302 & Tardive (bittervariety) & Asturias (Spain) & Traditional & 715.31 \\
\hline 2 & MR192 & $\begin{array}{l}\text { Jeptiska, Panenskeceske, Smiricke, } \\
\text { Jonathan, Starkinson, Wagnerovo, } \\
\text { Sudetskareneta, Ontario, Spartan }\end{array}$ & Czech Republic & Traditional & 2512.82 \\
\hline 3 & MR290 & Durona, Raxao, Collaos and Regona & Asturias (Spain) & Neumatic & 3047.41 \\
\hline 4 & MR300 & $\begin{array}{l}\text { French varieties with acidic } \\
\text { characteristics }\end{array}$ & France & Neumatic & 3811.49 \\
\hline 5 & MR296 & Asturian varieties & Asturias (Spain) & Neumatic & 4508.76 \\
\hline 6 & MR254 & $\begin{array}{l}\text { 30-20\% of Basque varieties and } \\
70-80 \% \text { Asturian varieties }\end{array}$ & $\begin{array}{l}\text { Basque Country } \\
\text { (Spain) }\end{array}$ & Neumatic & 4976.90 \\
\hline 7 & MR256 & $\begin{array}{l}\text { 30-20\% of Basque varieties and } \\
70-80 \% \text { Asturian varieties }\end{array}$ & $\begin{array}{l}\text { Basque Country } \\
\text { (Spain) }\end{array}$ & Neumatic & 6482.20 \\
\hline 8 & MR246 & $\begin{array}{c}8 \% \text { of French varieties and, } 92 \% \text { of } \\
\text { Asturian varieties }\end{array}$ & $\begin{array}{l}\text { France and / } \\
\text { Asturias (Spain) }\end{array}$ & Traditional & 7056.51 \\
\hline 9 & MR248 & $70 \%$ of Regona & Asturias (Spain) & Neumatic & 11348.16 \\
\hline
\end{tabular}

$\mathrm{DW}=\mathrm{dry}$ weight 


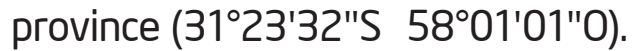

Bacterial strains were grown and kept on MYPGP-agar plates (Mueller-Hinton broth 1\% $(\mathrm{w} / \mathrm{v})$, yeast extract $1.5 \%(\mathrm{w} / \mathrm{v}), \mathrm{K}_{2} \mathrm{HPO}_{4} 0.3 \%$ $(w / v)$, glucose $0.2 \%(w / v)$, sodium pyruvate $0.1 \%(w / v)$, and agar $2 \%(w / v))$, and incubated at $37^{\circ} \mathrm{C}$ and $10 \%(\mathrm{v} / \mathrm{v}) \mathrm{O}_{2}$ for $48 \mathrm{~h}$ (Dingman \& Stahly, 1983; Nordström \& Fries, 1995). The bacterial inoculum was prepared in sterile peptone water (peptone $0.1 \%(w / v)$ and sodium chloride $0.85 \%(w / v)$ ) until a final optical density at $600 \mathrm{~nm}$ of 0.1 (0.5 of Mac Farland scale) using a UV-VIS spectrophotometer Spectrum SP-1103 (Spectrum Instruments Company Ltd., Shanghai, China) (Nordström \& Fries, 1995). Brain-heart infusion $(3.7 \%$, w/v) was used as a growth media for the bacterial strains in the performance of the broth microdilution assay. $P$. larvae growth was detected using resazurin sodium salt, which is a redox indicator, blue in its oxidized state and turns pink (reduced state) in the presence of aerobic bacteria growth. Bees (between 0 and 3 day old) used for toxicological assays were collected in the Santa Paula experimental apiary, Mar del Plata (Argentina) (3755'48"S 5740'59"0).

\section{Broth microdilution method}

The antimicrobial activities of the extracts were determined by the broth micro dilution method (Pellegrini et al., 2017) on four $P$. larvae strains (C1, C2, C6, C9). The extract concentration ranges were determined in which the minimum concentration of the extract and in vitro bacterial growth inhibition was observed (MIC (De Graaf et al., 2013)) and the minimum inhibitory concentration of the extract and in vitro bacterial growth inhibition was not observed (MNIC). The repeatability within day $(n=3)$ and between days $(n=3)$ of the method were also determined.

\section{Identification of bacterial strains}

The total DNA of the P. larvae strains under study was prepared from overnight cultures of the bacterial isolates grown in J medium (Hornitzky \& Nicholls, 1993). DNA was obtained using a commercial genomic DNA purification kit (Sigma). The DNA concentration and purity were checked using a NanoDrop 2000 spectrometer 169 (Thermo Fisher Scientific Com., Waltham, USA). Bacterial isolates were identified through the amplification of a specific $P$. larvae 16S rRNA gene fragment by the polymerase chain reaction (PCR) using primers PL5 and PL4 (Piccini et al., 2002).

ERIC genotyping of bacterial isolates was performed using primers designed by Versalovic et al. (1994). The PCR reactions were carried out with $1 \mathrm{U}$ Taq DNA polymerase (Invitrogen), $100 \mathrm{ng}$ of DNA, $0.0002 \mathrm{~mol} / \mathrm{L}$ of each of the four dNTP, $0.005 \mathrm{~mol} / \mathrm{L} \mathrm{MgCl}$ and $0.003 \mathrm{~mol} / \mathrm{L}$ of each primer in a total volume of $25 \mu \mathrm{L}$. The PCR conditions were a single denaturation step at $94^{\circ} \mathrm{C}$ for 5 minutes, 40 cycles of denaturation of the DNA template at $94^{\circ} \mathrm{C}$ for 1 minute, annealing of primers at $40^{\circ} \mathrm{C}$ for 2 minutes and extension of $P C R$ products at $65^{\circ} \mathrm{C}$ for 8 minutes. A final extension step was performed at $65^{\circ} \mathrm{C}$ for 16 minutes. Amplified products and two DNA markers, GeneRuler DNA Ladders 100 bp and GeneRuler DNA Laders 1 kb Thermo Fisher Scientific Co., were separated in a $0.8 \%$ agarose gel and stained with Gel Red (Olerup 187 SSP). The gels were photographed under UV light. The $\mathrm{PCR}$ reactions were carried out in triplicate.

\section{Toxicity analysis on bees}

The toxicity of apple pomace extract from against $A$. mellifera was analysed using the complete exposure method (Ruffinengo, 2005). The doses used per capsule were the MIC obtained for the apple pomace extracts against $P$. larvae. The freeze-dried extracts were dissolved in $20 \mathrm{~mL}$ methanol-water $(30: 70, \mathrm{v} / \mathrm{v})$, and $2 \mathrm{~mL}$ of the extract solution was placed on the base of a petri dish. The solvent was evaporated at r.t., and then ten worker bees were placed on the petri dish. The dishes were incubated at $30^{\circ} \mathrm{C}$ and $70 \%$ of relative humidity $(\mathrm{RH})$. Mortality of the bees was recorded after $24 \mathrm{~h}$ and $48 \mathrm{~h}$ (OECD, 1998). Five replicates for each extract were performed. The control was methanol-water (30:70, V/V).

\section{Statistical analysis}

The results of apple pomace extract toxicity 
were analyzed with a dose-response analysis. The Mantel-Cox Test was performed to compare concentrations used in each assay using GraphPad Prism version 7.00 for Windows, GraphPad Software, La Jolla California USA, www.graphpad.com.

\section{RESULTS}

In the first instance, the $P$. larvae strains were identified by the PCR using primers PL5 and PL4 specific for the amplification of the 16S rRNA gene fragment of this bacterium. A unique amplicon of $700 \mathrm{pb}$ characteristic of $P$. larvae was obtained which confirmed the identity of the bacterial strain isolates C1, C2, C3 and C4. Regarding strains genotyping, all $P$. larvaestrains showed the same DNA pattern ERIC primers regardless of the geographical origin. Based on comparison between the published previously obtained DNA fingerprints (Genersch et al., 2006; Genersch \& Otten, 2003) and reference strains (Alippi \& Aguilar, 1998; Antúnez et al., 2007), the isolates were classified as the ERIC I genotype. Four ERIC genotypes, ERIC I-IV, could be identified among $P$. larvae strains (Genersch et al., 2006). However, only ERIC I and II are the genotypes commonly found in nature, while ERIC III and IV have not been encountered in field isolates until now and exist only in culture collections (Alippi et al., 2004; Antúnez et al., 2007; Genersch \& Otten, 2003).

The antimicrobial activity of the phenolic extracts of nine apple pomaces provided by the cider making industry was determined by the broth micro dilution assay. The MIC values achieved from each extract against four strains of $P$. larvae are the same for the four strain and are shown in Tab. 2. The antimicrobial activity for the studied extracts against $P$. larvae ranged from $20 \mu \mathrm{g} / \mathrm{mL}$ to $150 \mu \mathrm{g} / \mathrm{mL}$. The extracts with lower total polyphenol contents, i.e. MR302 (715.31 gal. ac./ gW), MR192 (2512.82 و و gal. ac./g DW), and MR290 (3047.41 و gal. ac./g DW), show the best antimicrobial activities with MIC values of: $23 \mu \mathrm{g} / \mathrm{mL}, 20 \mu \mathrm{g} / \mathrm{mL}$ and $79 \mu /$ $\mathrm{mL}$ respectively.

Toxicity assays of apple pomace extracts on adult bees exhibit a maximum mortality of $20 \%$ after $48 \mathrm{~h}$ (Tab. 2), and the control presented a mortality of $2 \%$ at 48 hours of analysis. The comparison of all the survival curves with the Mantel-Cox Test is statistically significant $(p<0.005)$. The Tab. 3 shows results of the Mantel-Cox analysis, with statistically significant differences between the MIC obtained for each extract of apple pomace and the control. Fig. 1 shows the dose-response curves at 24 and $48 \mathrm{~h}$ for each apple pomace extract .

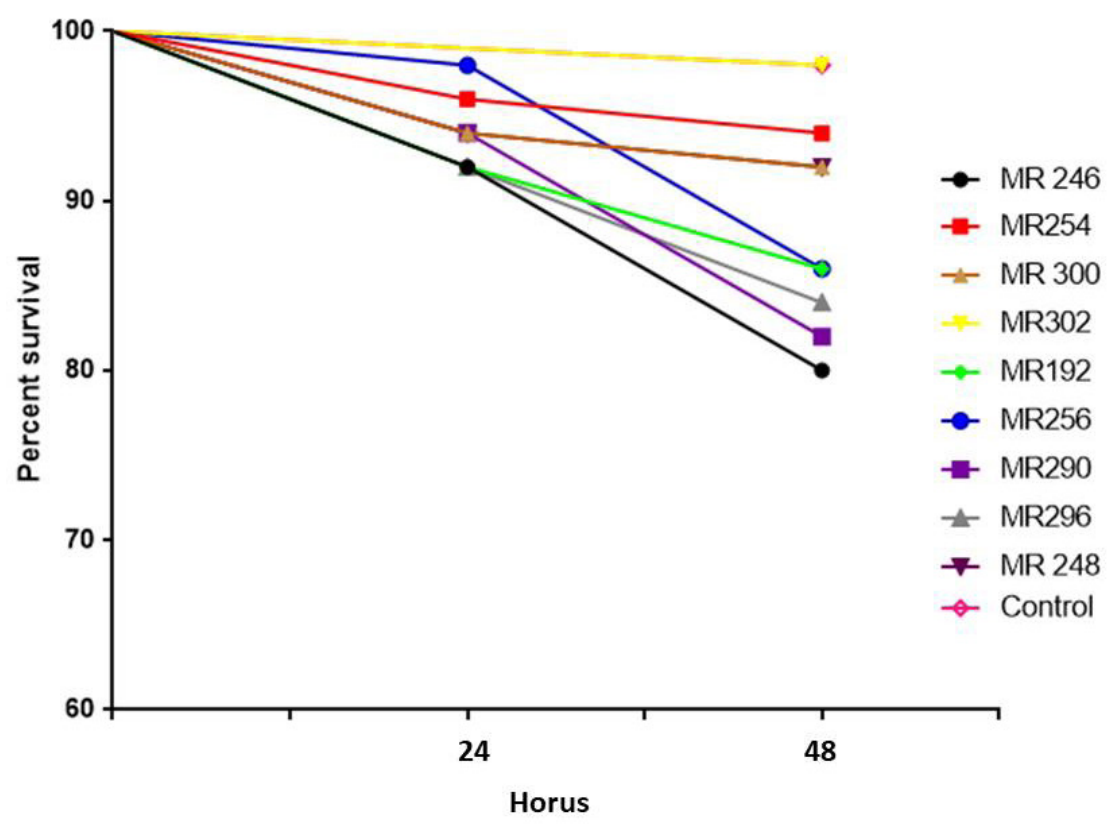

Fig. 1. Dose response curves of MICs obtained of the extracts of apple pomace studied on Apis mellifera. 
Table 2. Antimicrobial activity of the apple pomace phenolic extracts against $P$. larvae and their toxicity on A. mellifera

\begin{tabular}{cccccc}
\hline \multirow{2}{*}{ Extract } & MIC $(\mu / \mathrm{mL})$ & MNIC $(\mu \mathrm{g} / \mathrm{mL})$ & $\begin{array}{c}\text { Polyphenols Total } \\
(\mu g \text { gal. Ac./g DW })\end{array}$ & \multicolumn{2}{c}{ \% Mortality of A. mellifera } \\
\cline { 5 - 6 } & & 0 & 0 & 0 & $48 \mathrm{~h}$ \\
\hline Control & 0 & 18 & 715.31 & 0 & 2 \\
MR302 & 23 & 15 & 2512.82 & 8 & 2 \\
MR192 & 20 & 53 & 3047.41 & 6 & 14 \\
MR290 & 79 & 33 & 3811.49 & 6 & 18 \\
MR300 & 105 & 83 & 4508.76 & 8 & 8 \\
MR296 & 43 & 28 & 4976.90 & 4 & 16 \\
MR254 & 125 & 100 & 6482.20 & 2 & 6 \\
MR256 & 150 & 95 & 7056.51 & 8 & 14 \\
MR246 & 29 & 23 & 11348.16 & 6 & 20 \\
MR248 & 106 & 71 & &
\end{tabular}

MIC= Minimum Inhibitory Concentration

MNIC= Minimum Non Inhibitory Concentration

DW= Dry Weight

Table 3.

Comparison of Survival Curves using the Mantel Cox test for each MIC analyzed in the $A$. mellifera mortality test $(p<0.05)$

\begin{tabular}{|c|c|c|c|c|c|c|c|c|c|c|}
\hline & Control & MR302 & MR192 & MR290 & MR300 & MR296 & MR254 & MR256 & MR246 & MR248 \\
\hline Control & 0 & & & & & & & & & \\
\hline MR302 & $0.031^{\star}$ & 0 & & & & & & & & \\
\hline MR192 & 0.327 & $0.003^{\star *}$ & 0 & & & & & & & \\
\hline MR290 & 0.229 & $0.001^{\star \star}$ & 0.825 & 0 & & & & & & \\
\hline MR300 & 0.358 & 0.177 & 0.064 & $0.039 *$ & 0 & & & & & \\
\hline MR296 & 0.231 & $0.002^{* \star}$ & 0.826 & $>0.9999$ & $0.040^{\star}$ & 0 & & & & \\
\hline MR254 & 0.555 & 0.099 & 0.121 & 0.076 & 0.736 & 0.078 & 0 & & & \\
\hline MR256 & 0.788 & $0.016^{\star}$ & 0.467 & 0.339 & 0.237 & 0.343 & 0.388 & 0 & & \\
\hline MR246 & $0.013^{*}$ & $<0.0001^{\star * \star}$ & 0.118 & 0.175 & $0.001^{\star *}$ & 0.177 & $0.003^{\star \star}$ & $0.023^{*}$ & 0 & \\
\hline MR248 & $>0.999$ & $0.031^{*}$ & 0.327 & 0.229 & 0.358 & 0.231 & 0.555 & 0.788 & $0.013^{*}$ & 0 \\
\hline
\end{tabular}

\section{DISCUSSION}

The antimicrobial activity for the studied extracts against $P$. larvae ranged from $20 \mu \mathrm{g} /$ $\mathrm{mL}$ to $150 \mu \mathrm{g} / \mathrm{mL}$, according to Michielin et al. (2009), and plant materials were classified as antimicrobial agents based on the MIC values of its extracts. Duarte et al. (2007) and Wang et al. (2008) classified the extracts as strong inhibitors for MIC value below $500 \mu \mathrm{g} / \mathrm{mL}$ moderate inhibitors for MIC between 600 and $1500 \mu \mathrm{g} / \mathrm{mL}$ and weak inhibitors for MIC above $1600 \mu \mathrm{g} / \mathrm{mL}$. This classification is useful to detect the potential biological activity of various plant materials. Based on this classification these extracts will be strong inhibitors.

Previous studies reported higher MIC values for different plant extracts on P. larvae (Achy- 
rocline satureioides, Calendula officinalis, Cariniana domestica, Nasturtium officinale, Scutia buxifolia Reiss, Laurus nobilis and Melia azedarach L.), than those obtained in the present work (Alonso-Salces et al., 2017). Coppo \& Marchese (2014) reviewed the activity of polyphenols as antimicrobial agents and found that these compounds exhibited antimicrobial activity when interfering with the physiology of the bacteria through diverse mechanisms, among them membrane's functions by suppressing the virulence factors or preventing biofilm formation. Further studies should be conducted to analyze which would be the mechanism of action of polyphenols present in the apple pomace extracts studied, and which phenolic families exhibited that activity against $P$. larvae. Brasesco et al. (2017) observed possible synergism among molecules and observed an antagonic relationship between the compounds when they were studying the binary mixtures of the major constituents of the essential oils with acaricidal activity against the ectoparasite mite Varroa destructor. Gende et al. (2010), in an attempt to improve antimicrobial activity and reduce resistance development, studied the in vitro administration of antibiotic in combination with another active ingredient (essential oils from Cinnamomum zeylanicum). The results indicated that synergism was observed only in $50 \%$ of the cases, while the effects were antagonistic for $33 \%$ of the studied isolates. Therefore, the possibility of antagonistic relationships among highly concentrated phenolic compounds present in the extracts should be further studied.

Toxicity assays of apple pomace extracts on adult bees exhibit a maximum mortality of $20 \%$ after 48h (Tab. 2). Reyes et al. (2013) evaluated the toxicity by complete exposure in bees of Flourensia fiebrigii, the extract did not show lethal effects on exposed bees during in vitro conditions even at the highest concentration assayed $(125 \mathrm{mg} / \mathrm{mL})$. These results indicated the potential use of plant extracts as natural antibiotics due to their low toxicity on bees (OECD, 1998) (Tab. 2). Additional studies on the toxicity mechanism action of apple pomace extracts on bees should be conducted. The application of the apple pomace extracts in the hive should also be further investigated.

Although some of the extracts analyzed in the present study showed higher MIC values than OTC, apple pomace extracts are still promising, since being natural products present fewer problems that synthetic antibiotics have, including the presence of residues in the beehive products and the occurrence of resistant strains (Martel et al., 2006). Furthermore the reuse of such agro-industrial residues as apple pomace generated in great quantity causes environmental problems as warned by governments and environmental protection institutions.

\section{ACKNOWLEDGEMENTS}

This work was funded by Proyect PICT 3264/2014 - PICT 0774/2017 FONCYT MINCYT, Argentina. Pablo Gimenez Martinez wishes to thank the Agencia Nacional de Ciencia y Tecnología, (MINCYT, Argentina), CONICET and CIC for his Ph.D. Grant.

\section{REFERENCES}

Agourram, A., Ghirardello, D., Rantsiou, K., Zeppa, G., Belviso, S., Romane, A., Giordano, M. (2013). Phenolic content, antioxidant potential, and antimicrobial activities of fruit and vegetable by-product extracts. International/ournal of Food Properties, 16(5), 10921104. https://doi.10.1080/10942912.2011.576446

Alippi, A. (1996). Characterization of isolates of Paenibacillus larvae with biochemical type and oxytetracycline resistance (Vol. 28): Revista Argentina de Microbiologia.

Alippi, A. M., \& Aguilar, O. M. (1998). Unique DNA fingerprint patterns of Paenibacillus larvae subsp. larvae strains. Journal of Apicultural Research, 374), 273-280. DOl: 10.1080/00218839.1998.11100983

Alippi, A. M., Reynaldi, F. J., López, A. C., De Giusti, M. R., Aguilar, O. M. (2004). Molecular epidemiology of Paenibacillus larvae larvae and incidence of American foulbrood in Argentinean honeys from Buenos 


\section{GIMÉEEE-MARTíNEEZ Et Hl. — Activity of polyphenols on Paenibacillus larvae}

Aires province. Journal of Apicultural Research, 43(3), 135-143. DOl: 10.1080/00218839.2004.11101124

Alonso-Salces, R. M., Cugnata, N. M., Guaspari, E., Pellegrini, M. C., Aubone, I., De Piano, F. G., Fuselli, S. R. (2017). Natural strategies for the control of Paenibacillus larvae, the causative agent of American foulbrood in honey bees: a review. Apidologie, 48(3), 387-400. DOl: 10.1007/s13592-016-0483-1

Antúnez, K., Piccini, C., Castro-Sowinski, S., Rosado, A. S., Seldin, L., Zunino, P. (2007). Phenotypic and genotypic characterization of Paenibacillus larvae isolates. Veterinary Microbiology, 124(1-2), 178-183. DOl: 10.1016/j.vetmic.2007.04.012

Brasesco, C., Gende, L., Negri, P." Szawarski, N., Eguaras, M., Ruffinengo, S., Maggi, M. (2017). Assessing in vitro acaricidal effect and joint action of a binary mixture between essential oil compounds (Thymol, Phellandrene, Eucalyptol, Cinnamaldehyde, Myrcene, Carvacrol) over the ectoparasitic mite Varroa destructor (Acari: Varroidae). Journal of Apicultural Science, 67(2), 203-215. DOl: 10.1515/jas2017-0008

Bravo, L. (1998). Polyphenols: chemistry, dietary sources, metabolism, and nutritional significance. Nutrition Reviews, 56(11), 317-333. D0l: 10.1111/ j.1753-4887.1998.tb01670.x

Cirilli, M., Latini, G., Cristofori, V., Ceccantoni, B., Luziatelli, F., Zecchini, M., Muleo, R., Ruzzi, M. (2015). Polyphenol traits, antimicrobial property and consumer preference of 'Italian Red Passion' apple genotypes and cultivar 'Annurca'. Acta Horticulturae, 1106. DOl: 10.17660/ActaHortic.2015.1106.29

Coppo, E., \& Marchese, A. (2014). Antibacterial activity of polyphenols. Current Pharmaceutical Biotechnology, 15(4), 380-390. DOl: 10.2174/13892010150 4140825121142

Damiani, N., Fernández, N. I., Porrini, M. P., Gende, L. B., Álvarez, E., Buffa, F., Eguaras, M. J. (2014). Laurel leaf extracts for honeybee pest and disease management: Antimicrobial, microsporicidal, and acaricidal activity. Parasitology Research, 173(2), 701-709.

\section{DOI: 10.1007/s00436-013-3698-3}

De Graaf, D. C., Alippi, A. M., Antúnez, K., Aronstein, K. A., Budge, G., De Koker, D., Dingman, D. W., Stahly, D. P. (1983). Medium promoting sporulation of Bacillus larvae and metabolism of medium components. Applied and Environmental Microbiology, 46(4), 860869.

Duarte, M., Ewerton, E. L., Delarmelina, C., Almeida Soares, A., Figueira, G., Sartoratto, A. (2007). Activity of essential oils from Brazilian medicinal plants on Escherichia coli. Journal of Ethnopharmacology, 777, 197-201. DOI: 10.1016/j.jep.2006.11.034

Evans, J. D. (2003). Diverse origins of tetracycline resistance in the honey bee bacterial pathogen Paenibacillus larvae. Journal of Invertebrate Pathology, 83(1), 46-50. DOl: 10.1016/s0022-2011(03)000399

Fuselli, S. R., De La Rosa, S. B. G., Gende, L. B., Eguaras, M. J., Fritz, R. (2006). Antimicrobial activity of some Argentinian wild plant essential oils against Paenibacillus larvae larvae, causal agent of American foulbrood (AFB). Journal of Apicultural Research, 45(1), 2-7. DOl: 10.1080/00218839.2006.11101304

Gende, L., Maggi, M., van Baren, C., di Leo, L., Bandoni, A., Fritz, R., Eguaras, M. (2010). Antimicrobial and miticide activities of Eucalyptus globulus essential oils obtained from different Argentine regions. Spanish Journal of Agricultural Research, 8(3), 642-650.

Gende, L. B., Principal, J., Maggi, M. D., Palacios, S. M., Fritz, R., Eguaras, M. J. (2008). Melia azedarach extract and essential oils of Cinnamomun zeylanycum, Mentha piperita and Lavandula officinalis as a control of Paenibacillus larvae. Zootecnia Tropical, 26(2).

Genersch, E., \& Otten, C. (2003). The use of repetitive element PCR fingerprinting (rep-PCR) for genetic subtyping of German field isolates of Paenibacillus larvae subsp. larvae. Apidologie, 34(3), 195-206. DOl: 10.1051/apido:2003025

Genersch, E., Forsgren, E., Pentikäinen, J., Ashiralieva, A., Rauch, S., Kilwinski, J., Fries, I. (2006). Reclassifica- 
tion of Paenibacillus larvae subsp. pulvifaciens and Paenibacillus larvae subsp. larvae as Paenibacillus larvae without subspecies differentiation. International Journal of Systematic and Evolutionary Microbiology, 56(3), 501-511. DOl: 10.1099/ijs.0.63928-0

Genersch, E. (2010). American Foulbrood in honeybees and its causative agent, Paenibacillus larvae. Journal of Invertebrate Pathology, 103(SUPPL. 1), S10-S19. DOl: 10.1016/j.jip.2009.06.015

Genersch, E. (2013). Standard methods for American foulbrood research. Journal of Apicultural Research, 52(1). DOI: 10.3896/ibra.1.52.1.11

Goulson, D., Nicholls, E., Rotheray, E., \& Botias, C. (2015). Qualifying pollinator decline evidence-response. Science (New York, N.Y.), 348(6238), 982. DOl: 10.1126/science.348.6238.982

Hansen, H., \& Brødsgard, C. J. (1999). American foulbrood: A review of its biology, diagnosis and control. Bee World, 80(1), 5-23.

Hornitzky, M. A. Z., \& Nicholls, P. J. (1993). I medium is superior to sheep blood agar and brain heart infusion agar for the isolation of Bacillus larvae from honey samples. Journal of Apicultural Research, 32(1), 5152. DOl: 10.1080/00218839.1993.11101287

Martel, A. C., Zeggane, S., Drajnudel, P., Faucon, J. P., Aubert, M. (2006). Tetracycline residues in honey after hive treatment. Food Additives and Contaminants, 23(3), 265-273. DOl: 10.1080/02652030500469048

Michielin, E. M. Z., Salvador, Ana A., Riehl, C. A. S., Smânia, A., Smânia, E. F. A., Ferreira, Sandra R. S. (2009). Chemical composition and antibacterial activity of Cordia verbenacea extracts obtained by different methods. Bioresource Technology, 10024), 6615-6623. D0l: 10.1016/j.biortech.2009.07.061

Mihai, C. M., Mârghitaș, L. A., Dezmirean, D. S., Chirilâ, F., Moritz, R. F. A., Schlüns, H. (2012). Interactions among flavonoids of propolis affect antibacterial activity against the honeybee pathogen PaenibacilIus larvae. Journal of Invertebrate Pathology, 170(1),

\section{8-72. D0l: 10.1016/j.jp.2012.02.009}

Miyagi, T., Peng, C. Y. S., Chuang, R. Y., Mussen, E. C." Spivak, M. S., Doi, R. H. (2000). Verification of oxytetracycline-resistant American foulbrood pathogen Paenibacillus larvae in the United States. Journal of Invertebrate Pathology, 75(1), 95-96. DOl: 10.1006/ jipa.1999.4888

Nordström, S., \& Fries, I. (1995). A comparison of media and cultural conditions for identification of Bacillus larvaein honey. Journal of ApiculturalResearch, 34(2), 97-103. DOl: 10.1080/00218839.1995.11100894

OECD. (1998). Test No. 214: Honeybees, Acute Contact Toxicity Test: OECD Publishing.

Pellegrini, M. C., Alonso-Salces, R. M., Umpierrez, M. L., Rossini, C., Fuselli, S. R. (2017). Chemical composition, antimicrobial activity, and mode of action of essential oils against Paenibacillus larvae, etiological agent of American Foulbrood on Apis mellifera. Chemistry \& Biodiversity, 14(4), el600382. DOl: 10.1002/ cbdv.201600382

Piccini, C., D’Alessandro, B., Antúnez, K., \& Zunino, P. (2002). Detection of Paenibacillus larvae subspecies larvae spores in naturally infected bee larvae and artificially contaminated honey by PCR. World Journal of Microbiology and Biotechnology, 18(8), 761-765. DOl: 10.1023/a:1020435703165

Ramirez-Ambrosi, M., Abad-Garcia, B., Viloria-Bernal, M., Garmon-Lobato, S., Berrueta, L. A., Gallo, B. (2013). A new ultrahigh performance liquid chromatography with diode array detection coupled to electrospray ionization and quadrupole time-of-flight mass spectrometry analytical strategy for fast analysis and improved characterization of phenolic compounds in apple products. Journal of Chromatography A, 1316, 78-91. DOl: 10.1016/j.chroma.2013.09.075

Reyes, M. G., Torres, M. J., Maggi, M. D., Marioli, J. M., Gil, R. R., Sosa, V. E., Uriburu, M. L., Audisio, M. (2013). In vitro inhibition of Paenibacillus larvae by different extracts and pure compounds from Flourensia spp. Industrial Crops Products, 50758). 


\section{GIMÉNEZ-MARTíNEZ ET HL. _ Activity of polyphenols on Paenibacillus larvae}

Ruffinengo, E., Floris, Faverin, Bailac. (2005). $\mathrm{LD}_{50}$ and Repellent Effects of Essential Oils from Argentinian Wild Plant Species on Varroa destructor. Journal of Economic Entomology, 98(3), 651-655. DOl: 10.1603/0022-0493-98.3.651

SENASA. (2016). Noticias: se recuerda que no esta permitido el uso de antibioticos en las colmenas. Retrieved from http://www.senasa.gob.ar/senasa-comunica/noticias/se-recuerda-que-no-esta-permitido-el-uso-de-antibioticos-en-las-colmenas

Singleton, V. L., \& Rossi, J. A. (1965). Colorimetry of Total Phenolics with PhosphomolybdicPhosphotungstic Acid Reagents. American Journal of Enology and Viticulture, 16(3), 144-158.
Thompson, T. S., Pernal, S. F., Noot, D. K., Melathopoulos, A. P., van den Heever, J. P. (2007). Degradation of incurred tylosin to desmycosin-Implications for residue analysis of honey. Analytica Chimica Acta, 586(1-2), 304-311. D0I: 10.1016/j.aca.2006.09.043

Wang, Y. S., He, H. P., Yang, J. H., Di, Y. T., Hao, X. J. (2008). New Monoterpenoid Coumarins from Clausena anisum-olens. Molecules, 13(4), 931-937. DOl: 10.3390/molecules13040931 